\title{
INTELECTUAIS “ORGÂNICOS” EM TEMPOS DE PÓS-MODERNIDADE
}

\author{
Giovanni Semeraro*
}

RESUMO: No Brasil, a recente crise política e cultural vem gerando um amplo debate para rediscutir a função dos intelectuais na sociedade. Tendo como pano de fundo as mudanças socioeconômicas no mundo, este texto apresenta algumas análises da nova configuração que os intelectuais vêm assumindo no contexto da pós-modernidade. Destaca a figura do intelectual desenhada por Marx, com a criação da filosofia da práxis, e retoma a função do "intelectual orgânico" delineada por Gramsci. O texto evidencia os traços originais que emergem das reflexôes de Gramsci, apresenta uma releitura de algumas de suas categorias e aponta caminhos para atualizá-las em relação ao nosso tempo.

Palavras-chave: Intelectuais. Educação. Política. Filosofia. Gramsci.

\section{“ORGANIC" INTELLECTUALS IN POST-MODERNITY}

ABSTRACT: In Brazil, the current political and cultural crisis allows for a wide discussion regarding the function of intellectuals in society. Considering the worldwide socio-economic changes, this text presents some analyses of the new role assumed by intellectuals in post-modernity. It highlights the intellectual figure drawn by Marx when creating his philosophy of praxis, and goes over the function of the "organic intellectual" as delineated by Gramsci. It stresses the original features emerging from Gramsci's reflections, presents a reinterpretation of some of his categorizations and points out ways of adapting them to our current situation.

Key words: Intellectuals. Education. Politics. Philosophy. Gramsci.

Doutor em Educação, professor de Filosofia da Educação da Universidade Federal Fluminense (UFF) e coordenador do Núcleo de Estudos e Pesquisas em Filosofia Política e Educação (NUfIPE). E-mail: gsemeraro@globo.com 


\section{O desenho do novo intelectual em Marx e Gramsci}

\section{A unidade de ciência e política em Marx}

E

m 1845, quando Marx e Engels escreviam a Ideologia alemã, o mundo das ordens não existia mais. Na Europa, a intensa atividade nas fábricas e a agitação política revolucionavam as relações sociais, provando que a sociedade podia ser recriada pela iniciativa e a audácia de diferentes protagonistas. Então, em contraposição à burguesia instalada nos centros de poder, também irrompiam no cenário da história classes organizadas de trabalhadoras que carregavam aspirações próprias e lutavam por um outro projeto de sociedade.

Nesse contexto, os intelectuais não podiam se limitar mais ao mundo das idéias e das palavras. Assim, enquanto lançava suas críticas ao idealismo abstrato, ao positivismo cientificista e ao materialismo vulgar, Marx mostrava, com seu envolvimento nas lutas operárias, que estava despontando um outro tipo de intelectual: um ser, ao mesmo tempo, cientista, critico e revolucionário.

Nascia, então, a filosofia da práxis. E, com ela, novos intelectuais politicamente compromissados com o próprio grupo social para fazer e escrever a história e, por isso, capazes de refletir sobre o entrelaçamento da produção material com as controvertidas práticas da reprodução simbólica.

Mais do que elucubrações mentais, agora se fazia necessário conhecer o funcionamento da sociedade, descobrir os mecanismos de dominação encobertos pela ideologia dominante e os enfrentamentos das classes na disputa pelo poder. Com isso, os intelectuais não podiam se esconder atrás da neutralidade cientifica e ficar alheios às contradições do seu tempo. Eram impelidos a se definir nos conflitos da história e a tomar partido.

A própria ciência descobria-se envolvida nessas vicissitudes. Para entender em profundidade os problemas humanos e sociais, de fato, os intelectuais precisavam estar sintonizados com as dinâmicas sociais, políticas e econômicas do seu tempo. Por isso, ao mesmo tempo em que Marx procura desvendar os mecanismos de acumulação do capital, defronta-se com os Philosophes que continuavam a acreditar em mudar o mundo só pelo pensamento e pelas atividades da consciência (Marx, 
1998b, p. 9). Diversamente dessa posição, Marx indicava que a fabricação de conceitos e de teorias não acontece no vazio da mente, mas dentro de determinados processos histórico-econômicos e em sintonia com seus protagonistas políticos. Desse modo, a compreensão do mundo humano tornar-se-ia tanto maior quanto mais os intelectuais analisassem as contradições dos centros de produção e mais próximos estivessem das revoltas dos injustiçados, os únicos que podiam introduzir um projeto universalizador de sociedade. Portanto, era preciso que os intelectuaispolíticos se colocassem no lugar das vitimas do sistema, adquirissem a ótica dos defraudados e se revestissem das suas energias revolucionárias para fazer parte do "movimento real que supere o estado de coisas existentes” (Marx, 1989, p. 32).

Marx estava convencido, de fato, que as classes desapropriadas e os povos saqueados possuíam a inteligência "objetiva”, o ponto de vista mais concreto e radical proveniente da violência sofrida, do trabalho alienado, das necessidades elementares desatendidas, das relações sociais e humanas dissolvidas. Assim, se a verdadeira face da sociedade burguesa encontrava-se nos trabalhadores explorados e nos territórios colonizados (Marx, 1978, p. 265), a partir destes também precisava ser encontrado o caminho da revolução para fazer avançar a história em direção à liberdade e à sociabilidade universal. Só o processo revolucionário romperia o círculo da exploração, inauguraria uma nova epistemologia, criaria um novo "individuo social” e traçaria as estratégias políticas para a emancipação dos subjugados, não se limitando a levantes eventuais da "multidão" anárquica que, incomodada, podia reivindicar mudanças ou buscar ansiosamente a modernização, favorecendo, assim, o contínuo reajuste do sistema.

A emergência de um projeto alternativo, originado no proletariado, e a conquista da sua hegemonia, com o apoio dos intelectuais, levariam, para Marx, a uma sociedade verdadeiramente democrática (Abensour, 1998, p. 83). Assim, enquanto desmascara o caráter ideológico do capitalismo e a sua funcionalidade à violência e à manutenção do poder centralizado, Marx promove a organização dos trabalhadores local e mundialmente e recria, de forma inaudita e desafiadora, a atividade político-intelectual, convencido de que "a filosofia encontra no proletariado as suas armas materiais, assim como o proletariado encontra na filosofia as suas armas espirituais" (Marx, 1983, p. 173). 


\section{A originalidade do intelectual orgânico de Gramsci}

Desde que havia sido desencadeada, a nova concepção de mundo inaugurada por Marx tinha municiado muitas organizaçôes operárias e inspirado diversos intelectuais e políticos. Em sintonia com essa visão, Gramsci também acreditava que a compreensão de si mesmo e das contradições da sociedade acontecem pela inserção ativa nos embates hegemônicos. Por isso, aprofunda a estreita ligação entre intelectuais, política e classe social, mostrando que a filosofia, tal como a educação, deve tornar-se "práxis política" para continuar a ser filosofia e educação (Gramsci, 1975, p. 1.066).

Consciente da centralidade dos intelectuais no mundo contemporâneo, Gramsci reserva a essa questão um espaço significativo em seus escritos. Ao vivenciar como poucos a nova figura do intelectual militante (Frosini, 2000, p. 108), capta as complexas dinâmicas de expansão da "sociedade civil", que vinha ampliando de forma inédita as expressões intelectuais na "superestrutura". Mas, em contraposição às teorias que na sua época defendiam a elitização dos intelectuais (Benda, 1979), que se assustavam com o avanço das massas (Ortega y Gasset, 1980), que desprezavam a democracia (Nietzsche, 1990, $\$ \$ 202-203$ ) ou separavam a política da ciência (Weber, 1993), Gramsci valoriza com singularidade o saber popular, defende a socialização do conhecimento e recria a função dos intelectuais, conectando-os às lutas políticas dos "subalternos" (Gramsci, 1975, p. $1.505-1506)$.

Em seus escritos, além de uma ampla gama de tipos de intelectuais (urbanos, industriais, rurais, burocráticos, acadêmicos, técnicos, profissionais, pequenos, intermediários, grandes, coletivos, democráticos etc.), encontra-se uma interpretação original das suas funçōes. Gramsci, de fato, rompe com o lugar comum que entendia os intelectuais como um grupo em si, solto no ar, "autônomo e independente" (idem, ibid., p. 1.513). Contra a mentalidade que definia os intelectuais a partir da sua qualificação interior, Gramsci (op. cit., p. 1.516) observa que "O erro metodológico mais difundido, ao que parece, consiste em ter procurado este critério de distinção no que é intrínseco às atividades intelectuais, ao invés de buscá-lo no conjunto do sistema de relações em que essas atividades (e, portanto, os grupos que as personificam) se encontram, no conjunto das relações sociais".

Deixando de considerá-los de maneira abstrata, avulsa, como casta separada dos outros, Gramsci apresenta os intelectuais intimamente entrelaçados nas relações sociais, pertencentes a uma classe, a um grupo social 
vinculado a um determinado modo de produção. Toda a aglutinação em torno de um processo econômico precisa dos seus intelectuais para se apresentar também com um projeto específico de sociedade:

Todo grupo social, ao nascer do terreno originário de uma função essencial no mundo da produção econômica, cria também, organicamente, uma ou mais camadas de intelectuais que conferem homogeneidade e consciência da própria função não apenas no campo econômico, como também no social e político: o empresário capitalista gera junto consigo o técnico da indústria, o cientista da economia política, o organizador de uma nova cultura, de um novo direito etc. (Idem, ibid., p. 1.513)

Daqui, a designação de intelectuais "orgânicos" distintos dos intelectuais tradicionais. Estes, para Gramsci, eram basicamente os intelectuais ainda presos a uma formação socioeconômica superada. Eram os intelectuais estagnados no mundo agrário do Sul da Itália. Eram o "clero", "os funcionários", "a casa militar", "os acadêmicos" voltados a manter os camponeses atrelados a um status quo que não fazia mais sentido. Distantes das dinâmicas socioeconômicas em fermentação do Norte da Itália, onde os "intelectuais de tipo urbano cresciam junto com a indústria e estavam ligados às suas vicissitudes" (idem, ibid., p. 1.520), os intelectuais tradicionais ficavam empalhados dentro de um mundo antiquado, permaneciam fechados em abstratos exercícios cerebrais, eruditos e enciclopédicos até, mas alheios às questões centrais da própria história. Fora do próprio tempo, os intelectuais tradicionais consideravam-se independentes, acima das classes e das vicissitudes do mundo, cultivavam uma aura de superioridade com seu saber livresco. A sua "neutralidade" e o seu distanciamento, na verdade, os tornavam incapazes de compreender o conjunto do sistema da produção e das lutas hegemônicas, onde fervia o jogo decisivo do poder econômico e político. Com isso, acabavam sendo excluídos não apenas dos avanços da ciência, mas também das transformações em curso na própria vida real.

"Orgânicos", ao contrário, são os intelectuais que fazem parte de um organismo vivo e em expansão. Por isso, estão ao mesmo tempo conectados ao mundo do trabalho, às organizações políticas e culturais mais avançadas que o seu grupo social desenvolve para dirigir a sociedade. Ao fazer parte ativa dessa trama, os intelectuais "orgânicos" se interligam a um projeto global de sociedade e a um tipo de Estado capaz de operar a "conformação das massas no nível de produção" material e cul- 
tural exigido pela classe no poder. Então, são orgânicos os intelectuais que, além de especialistas na sua profissão, que os vincula profundamente ao modo de produção do seu tempo, elaboram uma concepção ético-política que os habilita a exercer funçóes culturais, educativas e organizativas para assegurar a hegemonia social e o domínio estatal da classe que representam (Gramsci, 1975, p. 1.518). Conscientes de seus vínculos de classe, manifestam sua atividade intelectual de diversas formas: no trabalho, como técnicos e especialistas dos conhecimentos mais avançados; no interior da sociedade civil, para construir o consenso em torno do projeto da classe que defendem; na sociedade política, para garantir as funções jurídico-administrativas e a manutenção do poder do seu grupo social.

Como Gramsci a apresenta, desde os tempos de L'Ordine Nuovo, a função do novo intelectual, orgânico à dinâmica da sociedade e à conquista da hegemonia da sua classe, não pode mais consistir "na eloqüência" e nos ímpetos da "emoção", mas na interpenetração entre conhecimento cientifico, filosofia e ação política. Tal intelectual deve ser um "construtor, organizador, educador permanente", de modo que "da técnica-trabalho se chegue à técnica-ciência, à concepção humanista histórica, sem a qual se permanece 'especialista' e não se chega a 'dirigente' (especialista+político)" (idem, ibid., p. 1.551). A interconexão do mundo do trabalho com o universo da ciência, com as humanidades e a visão política de conjunto formam, em Gramsci, o novo princípio educativo e a base formativa do intelectual orgânico.

Embora distintas, entende-se porque economia, política, cultura e filosofia, para Gramsci, são partes orgânicas e inseparáveis da mesma realidade (idem, ibid., p. 1.591), a tal ponto que "Uma reforma intelectual e moral não pode deixar de estar ligada a um programa de reforma econômica. Pelo contrário, o programa de reforma econômica é exatamente a maneira concreta pela qual toda reforma intelectual e moral se apresenta” (idem, ibid., p. 1.561).

\section{A relação dialética entre intelectual orgânico e "povo-nação"}

Contudo, para Gramsci, a organicidade dos novos intelectuais está relacionada principalmente à sua profunda vinculação à cultura, à história e à política das classes subalternas que se organizam para construir uma nova civilização. Entre as páginas mais célebres dos seus escritos estão as 
que descrevem de maneira original e insuperável a relação entre intelectuais e "povo-nação" (Gramsci, 1975, p. 361-362; 1.042; 1.382-1.387; $1.505-1506 ; 1.635)$. Nessas páginas, podemos perceber claramente o abismo que separa a concepção dos intelectuais populares que "sentem" com "paixão" a vida dos "subalternos" e os intelectuais convencionais, funcionais à elite e especializados na administração e no controle da sociedade. Estes se revelam preocupados com a centralização do poder, com um universalismo abstrato (Losurdo, 1999, p. 121 e ss), com a coerção direta ou indireta. Os intelectuais orgânicos às classes populares, ao contrário, caracterizam-se pela democratização do poder, pela expansão dos direitos, pela eliminação da violência e do embuste. Ao desvendar as contradições na sociedade e ao socializar o poder, os intelectuais populares, por um lado, subvertem a concepção de dominação, de autoritarismo e de burocratismo, e, por outro, criam uma nova concepção de política fundada sobre o conceito de hegemonia, de democracia, de 'dirigentes' de uma nova civilização (Semeraro, 2003, p. 270-271).

Gramsci retrata a osmose profunda dos intelectuais com as camadas populares, reconhecidas como sujeitos ativos imbuídos de "espírito criativo", porque promove a universalização da intelectualidade. Quer dizer, está convencido de que todos têm a capacidade de pensar e agir, de elaborar conhecimentos, de acumular experiência, de ter uma sensibilidade, um ponto de vista próprio. Nesse sentido, combatendo a noção abstrata, aristocrática e restrita de intelectual, Gramsci afirma que "Todos são intelectuais (...). Porque não existe atividade humana da qual se possa excluir alguma intervenção intelectual" (Gramsci, 1975, p. 1.516). Até no trabalho mais mecânico e alienado há sempre um componente reflexivo, assim como todo ser humano tem uma cultura e forma-se uma concepção de mundo no interior do seu ambiente social e do seu grupo. A capacidade intelectual, portanto, não é monopólio de alguns, mas pertence a toda a coletividade, tanto no sentido diacrônico (quando se considera o acúmulo de conhecimento ao longo da história), como no sentido sincrônico (quando se busca compreender as interconexões que formam o mundo em que vivemos).

Daqui, a insistência em reconhecer a relação de reciprocidade entre sujeitos que aprendem e ensinam ao mesmo tempo (idem, ibid., p. 1.331). O exercício da intelectualidade, portanto, função da inteira coletividade, é dialético, o que justifica em Gramsci a formulação de "intelectual coletivo" e de "filósofo democrático" (idem, ibid., p. 1.332). As- 
sim, embora alguns tenham funções mais acentuadamente intelectuais na sociedade, o grau dessa atividade entre seus componentes é apenas quantitativo, nunca qualitativo. Isso quer dizer que o desempenho de diferentes funções "intelectuais" nunca deve justificar hierarquias ou divisão de classes na sociedade. Com essa visão, as reflexões de Gramsci passam longe da concepção de uma "intelligentsia" livremente "flutuante" e acima das partes, dotada de uma missão especial e de capacidades "objetivas" que, desde Mannheim (1986), têm ocupado muitas discussões contemporâneas. Guardam distância também das posições de Bobbio sobre a função dos intelectuais, o qual reedita, com a sua distinção entre o "ideólogo" e o "expert" (Bobbio, 1993, p. 117), entre o filósofo e o técnico (p. 140 e 159), o dualismo estabelecido por M. Weber (1980, p. 87 e ss) entre a "ética da convicção" e a "ética da responsabilidade", tão caro aos liberais e à maioria dos nossos políticos.

Na III tese sobre Feuerbach, Marx já havia apontado para a relação recíproca transformadora entre "circunstâncias" e educação (Marx, 1998a, p. 100). Mas Gramsci explicita e aprofunda essa inseparável relação dialética entre intelectual e mundo circunstante, entre estrutura e superestrutura, entre o que está dado e a iniciativa de sujeitos organizados, de modo a gerar uma "catarse" pessoal e social, um processo da subjetivação ético-política que caracteriza a construção do conhecimento e a prática coletiva de ensino-aprendizagem: "A personalidade histórica de um filósofo individual resulta também da relação ativa entre ele e o ambiente cultural que ele quer modificar, ambiente que reage sobre o filósofo e, obrigando-o a uma contínua autocrítica, funciona como "mestre" (Gramsci, 1975, p. 1.331). Isso significa que a escola, embora necessária, como mostra o interesse de Gramsci em recriá-la profundamente (cf. particularmente o Caderno 12), não é o único espaço para a formação de intelectuais. Para essa tarefa, contribuem também o partido, a fábrica, a igreja, a atividade política, a participação nas organizaçóes, nos movimentos sociais e culturais etc.

Essa visão totalmente inovadora e revolucionária rompe com a concepção do intelectual "superior" e separado, com o filósofo "detentor da verdade" e guia da pólis que se formou a partir da tradição platônica do "filósofo-rei". As idéias de Gramsci passam a fundamentar a formação dos novos intelectuais na práxis hegemônica dos subalternos, cujas lutas teóricas e práticas buscam criar uma outra filosofia e uma outra política, capazes de promover a superação do poder como dominação e construir efetivos projetos de democracia popular. 
Em sintonia com o marxismo e pela influência proveniente de Gramsci, muitos intelectuais no século passado chegaram a se "engajar" em partidos dos trabalhadores, em movimentos populares, mobilizaram lutas pela independência dos povos colonizados, pela libertação das ditaduras e pela democratização dos direitos sociais (Sartre, 1994; Lahuerta, 2001).

Nas últimas décadas, no entanto, a derrota do comunismo soviético, o triunfo do neoliberalismo e a difusão da cultura pós-moderna foram delineando um outro perfil de intelectual que acabou prevalecendo na nossa sociedade.

\section{A re-configuração do intelectual pela pós-modernidade}

A partir da segunda metade dos anos de 1970, um novo ciclo do capitalismo e a sua contraditória recomposição desencadearam profundas transformaçóes nos processos produtivos, nas práticas políticas e na função dos intelectuais.

O mundo do trabalho, remodelado pela informática e pela microeletrônica, passou a incorporar novos conhecimentos, gerando uma complexa analítica simbólica que exige um preparo intelectual mais apurado dos seus operadores. Com a revolução digital e a redução dos grandes conjuntos industriais, as categorias dos trabalhadores e as organizações de massa vieram se encolhendo. A velocidade e a diversificação na produção fragmentaram ainda mais os operários e conseguiram camuflar melhor as feiçōes da dominação, desconcertando a compreensão da realidade e as formas tradicionais de lutas políticas (Hardt \& Negri, 1995, p. 49 e ss).

Sofisticado e flexível, nunca o capital se tornou tão abrangente como nessas últimas décadas. Por meio da "indústria cultural”, submeteu o conhecimento aos desígnios da produtividade e do mercado, subsumindo, praticamente, toda as esferas da vida social. Difuso por toda parte, parece ter chegado a realizar o seu sonho mais ambicioso: tornarse poder impessoal, "inconsciente social” (Finelli, 2003, p. 104), máquina que marcha por própria conta, separado do trabalho vivo e do incômodo das revoltas operárias. Sem rosto e sem lugar, o novo soberano hoje se impóe, feito oráculo hermético, pelos indicadores econômicos anunciados todos os dias e por um dilúvio de informações que anulam a reflexão e a interlocução. Longe dos problemas da emancipação humana 
e imune às investidas da política, essa forma de poder encontra sua lógica mais acabada na cultura pós-moderna, que aprofunda o processo de esvaziamento do concreto pelo abstrato, reduzindo-o à invisibilidade e ao simulacro (Jameson, 1996, p. 85 e ss).

Nesse contexto, a figura do intelectual "engajado" entra em declínio e fala-se cada vez menos de intelectuais "orgânicos", das "classes" trabalhadoras, de "militantes" e de educadores populares. Por toda parte, despontam gestores, intelectuais céticos e políticos pragmáticos. As convicçóes de princípio, a visão de conjunto e a revolução são suplantadas pela incerteza e o pensamento da "errância" (Vattimo, 1996, p. 182), pelo gosto do particular e o narcisismo privado. Sob a forte influência do neoliberalismo na economia e da pós-modernidade na cultura, muitos intelectuais foram gradualmente deslocados do chão da fábrica e dos movimentos de massa para o campo do marketing, da estética e do fantasmagórico cenário da "vídeo-esfera".

A crise do intelectual popular acontece não apenas devido à "revolução tecnológica", mas também pela dissolução dos "sujeitos coletivos", pela relativização dos valores públicos, pela derrota do comunismo, pela indistinção entre esquerda e direita e pelo revisionismo imposto às revoluções.

Assim, ao longo dessas últimas duas décadas, vimos emergir como onda avassaladora uma crescente categoria de intelectuais que se disseminaram na mídia, na publicidade, no entretenimento, em Organizaçôes Não-Governamentais (ONGs), em serviços administrativos e no controle do sistema. Ficamos sabendo que havíamos ingressado na era da imagem, da "sociedade do conhecimento", da informação "just in time", na época do "capital cultural", na qual o saber deve ser servido como mercadoria nas formas folhetinescas para garantir a atração do "grande público". O emblema político do "Príncipe" de Maquiavel, re-configurado depois pelo "Moderno Príncipe" (Gramsci, 1975, p. 1.558), passa a ser desempenhado hoje pelo "Príncipe Eletrônico", que redesenha um novo, complexo e contraditório palco da política e da atividade intelectual (Ianni, 2003, p. 141 e ss). Em um mundo em que a imagem conta mais do que o produto, alastra-se a convicção de que o que não passa na mídia não existe. Não surpreende, portanto, se as tecnologias informáticas, eletrônicas e cibernéticas, dominadas por gigantescos conglomerados internacionais, tomam conta de todas as esferas da vida humana, atraindo muitos intelectuais a seu serviço. 
Assim, hoje, para a sua formação, o intelectual é compelido a tornar-se especialista da imagem, do som, dos jogos de linguagem, das virtualidades eletrônicas. No mundo das sensaçôes, das modas e dos rápidos contágios de massa, é fundamental que se aprenda, acima de tudo, a manejar a arte da aparência. Por isso, chega-se a falar no fim do intelectual político-pedagógico vinculado à escrita, à escola, ao partido, às organizações populares. O que se celebra agora é o advento da inteligência na "vídeo-esfera", no simbolismo e nas criaçoes instantâneas, nos "spots" comerciais e nos "insigth" (Sirinelli, 2003, p. 189). O intelectual "clássico", cultor da razão e da cosmovisão, da paciência histórica e da pedagogia política popular, é suplantado pela "inteligência emocional" e pelos recursos tecnológicos. O objetivo da "vídeo-esfera” não é a educação - ranço iluminista! - mas o entretenimento e a sedução. A busca da verdade, da justiça, do universal e a visão inspirada na história, na dialética, na totalidade etc. tornaram-se meta-narrativas e produtos autoritários. Em seu lugar, entram o regozijo da des-construção, a elucubração sobre o fragmento, o gosto pela indefinição, a preocupação estilística e ornamental. Vangloriando-se da sua impotência, o intelectual é solicitado a abandonar "as certezas" da filosofia e os projetos da política para entregar-se ao fluxo da narrativa e do romance (Rorty, 1999, p. 263; 2001, p. 98).

Depois dos clérigos dogmáticos na era da cristandade e dos cientistas do saber prático no mundo moderno, a maior parte dos intelectuais funcionais à classe dominante da nossa época precisa conformar o conhecimento às exigências dos novos donos do poder. Assim, temos hoje uma legião de intelectuais midiáticos e evanescentes em conformidade com a natureza do capital financeiro, dos fluxos da mercadoria e da informação. Entende-se porque ao capital especulativo, que quer lucrar sem se comprometer com a produção, corresponde o "intelectual ficcional" que discursa sem dizer nada.

Os efeitos desse fenômeno se refletem no interesse de uma multidão de intelectuais por um profissionalismo acrítico e hiperconcorrencial. Algo parecido acontece na política e na filosofia, onde se desqualifica o pensamento critico e proliferam os "cientistas", onde os humanistas foram se eclipsando diante dos gestores, os estadistas diante dos estatísticos, os midiáticos substituíram os educadores, as sondagens de opinião tomaram o lugar dos debates democráticos, os lobbies dispensaram as organizações sociais. Para a nova ordem imposta pelo capital, de fato, só 
serve a formação de uma inteligência tecnológico-utilitarista, não uma formação ético-política.

Estaríamos assistindo à decadência dos intelectuais político-pedagógicos que, de militantes, críticos e pesquisadores, estariam passando a intérpretes, gerentes, divulgadores? Faz sentido, então, falar ainda em "intelectual orgânico" às classes trabalhadoras em uma sociedade na qual as organizações de classe, os próprios partidos e os sindicatos custam a se justificar? Onde qualquer dissenso se desintegra na voragem do sistema e não parecem existir alternativas? Será que o "novo" intelectual desenhado por Marx e Gramsci estaria vencido e superado pela função cada vez mais virtual da produção e do conhecimento?

\section{O contraponto de Gramsci à virtualidade pós-moderna e à crise política}

\section{A evasão pós-moderna e o intelectual da práxis}

Em Marx, como em Gramsci, não há cruzadas iconoclastas contra os avanços científicos e tecnológicos. Pelo contrário, em sintonia com o próprio tempo, eles se utilizam com maestria dos meios mais modernos de investigação e de comunicação. Como vimos, Gramsci não é indulgente com o mundo provinciano e estagnado do Sul da Itália, quando comparado com as dinâmicas do Norte e do "americanismo e fordismo". Mas, também, não facilita o surgimento de intelectuais populistas e improvisados. Em muitas ocasiões, Gramsci defende uma ampla e rigorosa formação do intelectual orgânico, uma vez que a filosofia da práxis, além de representar "o coroamento de todo o movimento de reforma moral e intelectual" (Gramsci, 1975, p. 1.448), deve ser a reinvenção de um novo intelectual que sabe sintetizar o melhor da filosofia, da política, da economia, da ciência e da arte (Gramsci, 1996, Carta de 1/8/1932).

Hoje, as novas ferramentas à disposição dos intelectuais não devem ser menosprezadas. Embora Gramsci esteja aberto ao novo, não o aceita acriticamente. Assim como o trabalhador deve se modernizar, tornando-se cientificamente especializado e tecnicamente habilidoso até as fronteiras mais avançadas do conhecimento e da produção, sem cair na mecanização e na escravidão do sistema, também o intelectual deve estar atualizado e desenvolver pesquisas inovadoras, sem se deixar "taylorizar" e comprar. 
Mas não é suficiente se defender do risco de revolução passiva inerente a toda modernização. O intelectual orgânico popular, para Gramsci, deve alcançar as fronteiras mais avançadas do conhecimento e da tecnologia sem nunca perder a referência às lutas hegemônicas da sua classe. Além disso, também para não estagnar em um marxismo dogmatizado, é necessário promover a sua "traducibilidade" (Baratta, 2004, p. 225-241) para um tempo como o nosso, que se depara com outras feições de sociedade, com o surgimento de novos atores políticos, com novas formas de luta e com diferentes sensibilidades trazidas pela própria pós-modernidade.

Naturalmente, esse processo de tradução deve ser aplicado também à leitura de Gramsci. Mesmo assim, o essencial das suas reflexões sobre os intelectuais guarda sua atualidade até hoje. Nelas, emerge clara a distinção entre os intelectuais "funcionais" à dominação e os intelectuais "orgânicos" aos que lutam para superá-la. Em outras palavras, entre os intelectuais pragmáticos, que se colocam à disposição de uma sociedade gerenciada para poucos, e os que se envolvem com as organizações populares para construir uma democracia realmente "orgânica" para todo o corpo social, não apenas para uma parte dele.

$\mathrm{Na}$ extensa "guerra de posição" que virou o nosso mundo atual, os intelectuais orgânicos ao capital transnacional "lutam constantemente para mudar as mentes e expandir os mercados" (Said, 1994, p. 4). Mais do que "orgânicos", na verdade, os intelectuais funcionais às classes dominantes fazem prestação de serviço a seus condomínios de luxo, não à pólis. "Cães de guarda" (Nizan, 1970) de patrōes e "agentes imediatos" (Gramsci, 1975, p. 634) ao poder de plantão, são incapazes de criar uma autocrítica do grupo que representam e de apresentar projetos de alcance ético-político.

Os intelectuais orgânicos aos dominados, ao contrário, estão convencidos de que "a verdade é revolucionária". Portanto, não abdicam a formar consciências críticas e a construir um "bloco histórico" (uma articulação dialética) entre estrutura e superestrutura (economia e cultura), entre sociedade civil e sociedade política, de maneira a superar a relação vertical entre governantes e governados e a separação entre intelectuais e massa. Estão convencidos - como Gramsci - de que

A filosofia da práxis não tende a resolver pacificamente as contradições existentes na história e na sociedade, mas é a própria história de tais contradições; não é o governo de grupos dominantes para ter o consenso e exercer a 
hegemonia sobre as classes subalternas; mas é a expressão destas classes que querem educar a si mesmas para a arte do governo e têm interesse em conhecer todas as verdades, também as desagradáveis, e evitar os enganos (impossíveis) da classe superior e até de si mesma. (Gramsci, 1975, p. 1.320)

Como observamos no início, Marx havia indicado que na história dos vencidos há uma verdade que não se consegue suprimir. "Escovada a contrapelo" - dirá Walter Benjamin (1985, p. 225) mais tarde -, essa história revela os horrores da sociedade tecno-burocrática. Ao deixar de considerar a história humana na sua totalidade e evadir das contradições que hoje se acentuam no mundo, os intelectuais dos condomínios pósmodernos perdem a sua liberdade crítica, a consciência histórica e a própria "organicidade" ao seu grupo.

Concentrados nos meios de comunicação e nos serviços mais sofisticados, os intelectuais do sistema só aparentemente asseguram a hegemonia do grupo ao qual pertencem. $\mathrm{Na}$ verdade, nenhuma imagem televisiva substitui o envolvimento direto do intelectual com as lutas sociais, nenhuma reengenharia educativa substitui a relação mestre-aluno, nenhuma propaganda eleitoral substitui a ligação do partido com a realidade de suas bases.

Técnicos e publicitários de uma sociedade sem projeto como a nossa, seus intelectuais afastam-se de uma outra característica fundamental presente em Gramsci: o reconhecimento do saber popular, a construção democrática e coletiva de um projeto público de sociedade. Para Gramsci, de fato, mais do que a centralidade do intelectual e a sofisticação de um grupo de vanguarda irradiador de verdades, é importante "a elevação moral e intelectual das massas" até as fronteiras mais avançadas da ciência, de modo a arrancar da classe dominante o monopólio do conhecimento que, na era digital, pode aprofundar ainda mais o fosso com as classes espoliadas.

As condições materiais para universalizar as ferramentas tecnológicas e para a interatividade estão dadas no mundo de hoje. Trata-se, agora, de fazer com que a circulação das informações e a criação do conhecimento não emanem de centros monopolizados e exclusivos, mas sejam construídas democraticamente por todos, local e mundialmente, no trabalho, nas escolas, nas organizações políticas, nos centros culturais, na diversidade de grupos e de etnias.

Então, tem ainda sentido falar em "intelligentsia" de um corpo especial de pessoas que produzem idéias e teorias para a sociedade e for- 
mam consciências? E qual é a função do partido, do "Moderno Príncipe" intelectual idealizado por Gramsci?

\section{O pragmatismo dos partidos e os intelectuais da grande política}

O intelectual que emerge dos escritos de Gramsci é "orgânico" (voltado a impulsionar a sociedade inteira, não apenas uma parte), democrático (determinado a superar a relação de poder-dominação) e popular (sintonizado com a cultura e os projetos hegemônicos dos "subalternos").

Entende-se, então, porque Gramsci afirma: "Eu amplio muito a noção de intelectual, não me limitando à noção corrente que se refere aos grandes intelectuais (...). Justamente na sociedade civil operam os intelectuais (Lettere dal carcere, 7 de setembro de 1931)". Avanço semelhante opera com a concepção ampliada de Estado (Gramsci, 1975, p. 810-811), quando articula de forma dialética sociedade política e sociedade civil, superando com isso a concepção de uma entidade separada e superior. Em sintonia com essa linha de pensamento, nele há também uma concepção ampliada de partido, incluindo nessa tarefa a função de um jornal, de uma revista, de um centro cultural, de grupos e movimentos organizados na sociedade civil. Em todos esses casos, as preocupações de Gramsci são as mesmas: os governantes e os governados, o instituído e o instituinte precisam interagir dialeticamente para chegar a construir um organismo social com dimensões ético-políticas. Assim, diversamente de posições que hoje reeditam o naturalismo "organicista" ou o pragmatismo holista, a organicidade de Gramsci apresenta-se em termos de uma luta social, histórica e política para construir a hegemonia da democracia popular (Semeraro, 2005, p. 28-39).

Não importa o lugar em que o intelectual desempenha a sua função, se no partido, no Estado, no sindicato, nos movimentos populares, nas organizações sociais e culturais ou na academia. O que conta para Gramsci é a sua vinculação de classe, a relação democrática que o intelectual estabelece e o horizonte ético-político que descortina, isto é, a capacidade de promover um projeto socializador que reconheça os subjugados como sujeitos políticos. Nesse sentido, há em Gramsci uma relação estreita entre o conceito de "orgânico" e o de "ético-político", se considerarmos que os dois remetem à universalização da democracia popular. E essa só acontece com a construção de uma hegemonia capaz de entrelaçar em unidade subjetividades individuais e "vontade coletiva", de transformar em li- 
berdade a necessidade, quer dizer, de operar o processo de "catarse", de subjetivação, que é "o ponto de partida de toda a filosofia da práxis" (Gramsci, 1975, p. 1.244). Então, em Gramsci, os intelectuais são "orgânicos" a um partido, a um grupo social, ao Estado, enquanto trabalham para superar o momento "econômico-corporativo" e o momento jurídicoadministrativo e se lançam ao lado dos "subalternos" para criar a fase da universalidade "ético-política" (idem, ibid, p. 1.584).

Em tempos pós-modernos, os intelectuais "orgânicos" não se tornaram obsoletos, mas encontram-se diante de novas tarefas. Como nunca, precisam aprender com Gramsci a difícil arte de lidar com a diversidade sem cair no relativismo, de lutar contra os dogmas sem deixar de buscar a verdade, de respeitar a particularidade sem se pulverizar, de construir a unidade sem transformá-la em uniformidade, de realizar a democracia popular contra os simulacros pós-modernos. Se essas considerações estiverem certas, torna-se necessário pensar também novos partidos com dimensões éticas e políticas capazes de "fundar novos Estados" (idem, ibid., p. 1.111).

No Brasil, ao longo dessas últimas duas décadas, inúmeros intelectuais com posições de resistência à ditadura e cumplicidade com os movimentos populares passaram a "funcionários" de partido e a gerentes técnico-administrativos dos aparelhos do poder governamental. Aos poucos, vimos surgir uma legião de especialistas em estratégias eleitorais, em profissionais da imagem, em artimanhas jurídicas, em hibridismo ideológico e tráfico de influência.

Esse processo tem sido uma das causas da profunda crise política, hoje em curso, que deixa muitos intelectuais calados e dissemina o descrédito na democracia e no sistema representativo em uma sociedade consternada.

Enquanto os partidos e seus intelectuais permanecerem na esfera do econômico, da burocracia e do populismo, não haverá o salto para a esfera ético-política, a única em que é possível pensar o país como um todo e em condições de universalizar direitos. Por isso, contrariamente ao que se pensa, nunca como hoje o Brasil precisou tanto de novos intelectuais "orgânicos". Dos que - como Gramsci nos lembra - forem capazes de se lançar em direção a uma das mais urgentes e audaciosas tarefas:

A partir do momento em que um grupo subalterno se torna realmente autônomo e hegemônico, suscitando um novo tipo de Estado, nasce concretamente a exigência de construir uma nova ordem intelectual e moral, ou 
seja, um novo tipo de sociedade e, portanto, a exigência de elaborar os conceitos mais universais, as armas ideológicas mais sofisticadas e decisivas. (Gramsci, 1975, p. 1.509)

Recebido em fevereiro de 2006 e aprovado em abril de 2006.

Referências bibliográficas

ABENSOUR, M. A democracia contra o Estado: Marx e o momento maquiaveliano. Belo Horizonte: UFMG, 1998.

BARATTA, G. As rosas e os cadernos. Rio de Janeiro: DP\&A, 2004.

BENDA, J. Il tradimento dei chierici. Turim: Einaudi, 1979.

BENJAMIN, W. Magia e técnica, arte e política: ensaios sobre literatura e história da cultura. In: Benjamin, W. Obras escolhidas. São Paulo: Brasiliense, 1985. v.1.

BOBBIO, N. Il dubbio e la scelta: intellettuali e potere nella società contemporanea. Roma: La Nuova Italia Scientifica, 1993.

FINELLI, R. O "pós-moderno": verdade do moderno. In: Coutinho, C.N.; TeIXeIra, A.P. (Org.). Ler Gramsci: ler a realidade. Rio de Janeiro: Civilização Brasileira, 2003. p. 99-112.

FROSINI, F. Il divenire del pensiero nei "Quaderni del carcere". Critica Marxista (nuova serie), Roma, n. 3/4, p. 108-120, 2000.

GRAMSCI, A. Quaderni del carcere. Turim: Einaudi, 1975.

GRAMSCI, A. Lettere dal carcere: 1926-1937. Palermo: Sellerio, 1996. $2 \mathrm{v}$.

HARDT, M.; NEGRI, A. Il lavoro di Dioniso: per la critica dello Stato postmoderno. Roma: Manifestolibri, 1995.

IANNI, O. Enigmas da modernidade-mundo. Rio de Janeiro: Civilização Brasileira, 2003.

JAMESON, F. Pós-modernismo: a lógica cultural do capitalismo tardio. São Paulo: Ática, 1996. 
LAHUERTA, M. Intelectuais e resistência: vida acadêmica, marxismo e política no Brasil. Caderno AEL, Campinas, n. 14/15, p. 35-53, 2001.

LOSURDO, D. L'universalismo difficile: diritti dell'uomo, conflitto sociale e contenzioso geopolitica. In: CotTuri, G. (Org.). Guerra individuo. Milano: Angeli, 1999. p. 103-135. (Democrazia e diritto, n. 1)

MANNHEIM, K. Ideologia e utopia. Rio de Janeiro: Guanabara, 1986. MARX, K. Il capitale. Roma: Riuniti, 1978.

MARX, K. Per la critica della filosofia del diritto pubblico di Hegel. In: MarX, K. Critica della filosofia hegeliana del diritto pubblico. Roma: Riuniti, 1983.p. 161-174.

MARX, K. Teses sobre Feuerbach. In: MARX, K.; Engels, F. A ideologia alemã (anexo). São Paulo: Martins Fontes, 1998a.

MARX, K.; ENGELS, F. A ideologia alemã. São Paulo: Martins Fontes, $1998 \mathrm{~b}$.

NEGRI, A. O poder constituinte. Rio de Janeiro: DP\&A, 1998.

NIETZSCHE, F. Além do bem e do mal. São Paulo: Cia das Letras, 1990.

NIZAN, P. I cani da guardia. Firenze: La Nuova Italia, 1970.

ORTEGA Y GASSET, J. A rebelião das massas. Rio de Janeiro: Livro Ibero-Americano, 1980.

RORTY, R. Ensaios sobre Heidegger e outros: escritos filosóficos II. Rio de Janeiro: Relume-Dumará, 1999.

RORTY, R. La filosofia dopo la filosofia: contingenza, ironia e solidarietà. Roma: Laterza, 2001.

SAID, E. Representations of the intellectual. London: Vintage, 1994.

SARTRE, J.-P. Em defesa dos intelectuais. São Paulo: Ática, 1994.

SEMERARO, G. Tornar-se "dirigente": o projeto de Gramsci no mundo globalizado. In: Coutinho, C.N.; Teixeira, A.P. (Org.). Ler Gramsci: ler a realidade. Rio de Janeiro: Civilização Brasileira, 2003. p. 261-273. 
SEMERARO, G. A filosofia da práxis e o (neo)pragmatismo de R. Rorty. Revista Brasileira de Educação, Campinas, n. 29, p. 95-104, 2005.

SIRINELLI, J.-F. A sociedade intelectual francesa no limiar de um novo século. In: Bastos, E.; Ridenti, M.; Rolland, O. (Org.). Intelectuais: sociedade e política. São Paulo: Cortez, 2002. p. 185-196.

VATTIMO, G. O fim da modernidade: niilismo e hermenêutica na cultura pós-moderna. São Paulo: Martins Fontes, 1996.

WEBER, M. Il lavoro intellettuale come professione. Turim: Einaudi, 1980.

WEBER, M. Ciência e política: duas vocações. São Paulo: Cultrix, 1993. 